\title{
Impact of reactor configurations on the performance of a granular anaerobic membrane bioreactor for municipal wastewater treatment
}

\author{
Cheng Chen ${ }^{\mathrm{a}}$, Wenshan Guo ${ }^{\mathrm{a}, *}$, Huu Hao Ngo ${ }^{\mathrm{a}}$, Soon Woong Chang ${ }^{\mathrm{b}}$, Dinh Duc Nguyen ${ }^{\mathrm{b}}$, \\ Phuoc Dan Nguyen ${ }^{\mathrm{c}}$, Xuan Thanh Buic, Yun Wu ${ }^{\mathrm{d}}$ \\ ${ }^{a}$ Centre for Technology in Water and Wastewater, School of Civil and Environmental Engineering, \\ University of Technology Sydney, Sydney, NSW 2007, Australia \\ ${ }^{b}$ Department of Environmental Energy \& Engineering, Kyonggi University, Republic of Korea \\ ${ }^{c}{ }^{1}$ Faculty of Environment and Natural Resources, University of Technology, Vietnam National \\ University-Ho Chi Minh, District 10, Ho Chi Minh City,Vietnam \\ d State Key Laboratory of Separation Membranes and Membrane Processes, Tianjin Polytechnic \\ University, Tianjin 300387, China \\ *Corresponding authors; E-mail addresses: wguo@uts.edu.au
}

\begin{abstract}
This study compared overall performance of an external granular anaerobic membrane bioreactor and a submerged granular anaerobic membrane bioreactor (EG-AnMBR and SGAnMBR, respectively), to determine which type of G-AnMBRs is more preferred for municipal wastewater treatment. Both systems presented similar COD removal efficiencies (over 91\%) and methane yield of $160 \mathrm{~mL} \mathrm{CH}_{4}$ (STP) (g COD removed) ${ }^{-1}$ although volatile fatty acids (VFA) accumulation was found in the SG-AnMBR. Membrane direct incorporation into the SG-AnMBR significantly affected the concentration and properties of microbial products (e.g. soluble microbial products (SMP) and extracellular polymeric substances (EPS)) in the cake layer, mixed liquor and granular sludge, as well as granular sludge size and settleability. The EG-AnMBR demonstrated less SMP and EPS in the mixed liquor and cake layer, which might reduce the cake layer resistance and lower the fouling rate. Liquid chromatographyorganic carbon detection (LC-OCD) analysis of foulant revealed that biopolymers along with low molecular weight neutrals and acids and building blocks were responsible for higher fouling propensity in the SG-AnMBR. It is evident that compared to the SG-AnMBR, the EGAnMBR serves as a better G-AnMBR configuration for municipal wastewater treatment due to less fouling propensity and superior granule quality.
\end{abstract}

Keywords: Granular anaerobic membrane bioreactor; Membrane fouling; Methane yield; Biogas; Soluble microbial products

\section{Introduction}

Anaerobic membrane bioreactors (AnMBRs) have gained particular interest for municipal wastewater treatment in recent years due to its competitive advantages (i.e., bioenergy production, quality effluent, low sludge disposal, high loading capacity, nutrient recovery, footprint efficiency, lower energy requirements, and decentralized operation) over the conventional anaerobic systems and aerobic MBRs (Mnif et al., 2012; Galib et al., 2016; Pretel et al., 2016). However, membrane fouling has remained as one of the most challenging issues impeding the progress of AnMBRs (Sanguanpak et al., 2015; Huang et al., 2012; Saleem et al., 2016), especially with high biomass concentration in widely used conventional AnMBRs (C-AnMBRs). 
In view of this concern, many researchers have devoted their efforts into developing various AnMBR configurations such as vibrating AnMBRs (V-AnMBRs) (Kola et al., 2014) Gas-lifting AnMBRs (Gl-AnMBRs) (Gimenez et al., 2012), anaerobic bio-entrapped membrane bioreactors (AnBEMRs) (Ng et al., 2014), anaerobic dynamic membrane bioreactors (AnDMBRs) (Saleem et al., 2016) and anaerobic membrane sponge bioreactors (AnMSBRs) (Kim et al., 2014) for sustainable fouling mitigation strategies. Granular anaerobic membrane bioreactor (G-AnMBR), a hybrid anaerobic biotechnology that incorporates the granular technology with membrane based separation, has offered a promising approach to the C-AnMBR in terms of fouling mitigation (Chen et al., 2016a). Unlike C-AnMBRs predominantly in the form of completely stirred tank reactor (CSTR) configuration, biomass retention is achieved by the spontaneous formation of granular sludge in G-AnMBRs without the need for mechanical mixing. The anaerobic granular bed is usually featured with total biomass concentrations ranging from 20 to $40 \mathrm{~g} \mathrm{~L}^{-1}$. All the biological reactions occurred within the dense sludge bed at the bottom of the upflow anaerobic granular bioreactor (UAGB). When combining UAGB with membrane filtration, the entrapment of most particulate organics by adsorption and biodegradation in the granular sludge bed allowed membrane module only being challenged by the supernatant of the granular sludge bed, thus reducing the organic loading to the membrane (Martin-Garcia et al., 2011; Ozgun et al., 2015). Hence, less apparent formation of dense cake layer and its consolidation occurred as compared to C-AnMBR (Ozgun et al., 2015). Martin-Garcia et al. (2013) confirmed the lower fouling potential in the G-AnMBR as compared to the C-AnMBR, due to the reduced solid and colloidal load (by a factor of 10 and 3) to the membrane. Furthermore, the critical flux test also revealed the G-AnMBR required much lower gas sparging intensity, resulting in lower energy demand for fouling control. The filtration performance of three MBRs (i.e. CAnMBR, G-AnMBR and conventional aerobic MBR) for domestic wastewater treatment was also investigated (Martin-Garcia et al., 2011). Comparing to the C-AnMBR, it was found that the G-AnMBR was characterized with 50\% lower mixed liquor suspended solids (MLSS) concentration and soluble microbial products (SMP), contributing to lower fouling rate than that of the C-AnMBR.

The predominated configuration of current G-AnMBR operation for municipal wastewater treatment was found as the external G-AnMBR (EG-AnMBR) where membrane filtration was applied as a polishing stage for UAGB effluent (Herrera-Robledo et al., 2010; Herrera-Robledo et al., 2011; Salazar-Pelaez et al., 2011a; Salazar-Pelaez et al., 2011b). In this case, membrane tank is usually situated after the main biological treatment process (i.e. UAGB) and the concentrate streams are not recycled back to the main bioreactor. The main advantages include undisturbed hydraulics in the UAGB, and the ease of operation and membrane cleaning. Nevertheless, Ozgun et al. (2015) elucidated that the EG-AnMBR may be encountered with the progressive increase in the SS loading on the membrane unit. Very few researchers employed submerged membrane in the SG-AnMBR to provide nearly absolute biomass retention and allow for operation at nearly infinite SRTs (Chu et al., 2005). Membrane, in this case, not only acts as a physical barrier for active biomass retention, but also promotes a general cultural adaptation to the prevailing organic loading conditions in the SG-AnMBR (Liu et al., 2013). On the other hand, Liu et al. (2012) pointed out membrane filtration could exacerbate sludge bioflocculation in the SG-AnMBR and induced greater cake resistance, resulting in more serious fouling. To date, no references have been found to compare the two mainstream G-AnMBRs for the treatment of municipal wastewater.

The objective of this study is, therefore, to determine which type of G-AnMBR configurations is favourable for municipal wastewater treatment. To this aim, a direct 
comparison of external and submerged membrane operation in G-AnMBR (namely EGAnMBR and SG-AnMBR) was conducted. The comprehensive evaluation of the two GAnMBRs included the investigation of treatment efficiencies, granules properties (e.g. particle size, settling velocity, extracellular polymeric substances (EPS), etc.), membrane fouling behaviour (transmembrane pressure (TMP), potential foulants, fouling resistance analysis), and renewable energy recovery (methane yield).

\section{Materials and methods}

\subsection{Synthetic wastewater}

Both EG-AnMBR and SG-AnMBR were fed with synthetic wastewater simulating the domestic wastewater just after primary treatment. The synthetic wastewater is comprised of organics and macronutrients, and trace nutrients. The synthetic wastewater was characterized by dissolved organic carbon (DOC) of 100-120 $\mathrm{mg} \mathrm{L}^{-1}$, chemical oxygen demand (COD) of 320 - $360 \mathrm{mg} \mathrm{L}^{-1}$, ammonia nitrogen $\left(\mathrm{NH}_{4}{ }^{+}-\mathrm{N}\right)$ of $5.2-6.5 \mathrm{mg} \mathrm{L}^{-1}$, nitrite nitrogen $\left(\mathrm{NO}_{2}{ }^{-}-\mathrm{N}\right)$ of $0-0.03 \mathrm{mg} \mathrm{L}^{-1}$, nitrate nitrogen $\left(\mathrm{NO}_{3}{ }^{-} \mathrm{N}\right)$ of $0.2-0.7 \mathrm{mg} \mathrm{L}^{-1}$ and orthophosphate $\left(\mathrm{PO}_{4}{ }^{3-}-\mathrm{P}\right)$ of 3.0 - $3.5 \mathrm{mg} \mathrm{L}^{-1}$ (COD: $\mathrm{N}: \mathrm{P}=100: 2: 1$ ). $\mathrm{NaOH}$ or $\mathrm{NaHCO}_{3}$ was used to adjust $\mathrm{pH}$ to 7 .

\subsection{Experimental setup and operating conditions}

Two G-AnMBRs with equal working volume of $4 \mathrm{~L}$, namely EG-AnMBR and SGAnMBR were operated in parallel at $20 \pm 0.5{ }^{\circ} \mathrm{C}$ in the Environmental Engineering lab at the University of Technology, Sydney. Both G-AnMBRs were fed with identical inoculated anaerobic sludge with similar initial sludge concentration $\left(21.48 \pm 0.98 \mathrm{~g} \mathrm{~L}^{-1}\right.$ for the EGAnMBR, $21.41 \pm 1.12 \mathrm{~g} \mathrm{~L}^{-1}$ for the SG-AnMBR) at the beginning of the experiments. For the EG-AnMBR, a polyvinylidence (PVDF) hollow fiber membrane with a pore size of $0.22 \mu \mathrm{m}$ and surface area of $0.06 \mathrm{~m}^{2}$ was immersed in the subsequent membrane tank located after the UAGB. Membrane tank was fed with the UAGB effluent and a suction pump was operated with an intermittent suction cycle of $8 \mathrm{~min}$ on and $2 \mathrm{~min}$ off to acquire permeate from the membrane module. While in the SG-AnMBR, an identical membrane module was directly immersed into the mixed liquor at the settling zone of the UAGB. Both systems were operated at a constant filtration rate of $7 \mathrm{~L} \mathrm{~m}^{-2} \mathrm{~h}^{-1}$, hydraulic retention time of $12 \mathrm{~h}$, and upflow velocity of $0.7 \mathrm{~m} \mathrm{~h}^{-1}$. The membrane fouling was indicated by development of the normalized TMP, which was recorded by a pressure transmitter. When TMP reached $30 \mathrm{kPa}$, G-AnMBR operation was terminated.

\subsection{Analytical methods}

DOC of the influent and effluent was measured using a DOC analyzer (Analytikjena Multi N/C 2000). The analysis of COD was carried out according to Standard Methods (APHA, 1999). $\mathrm{NH}_{4}{ }^{+}-\mathrm{N}, \mathrm{NO}_{2}{ }^{-}-\mathrm{N}, \mathrm{NO}_{3}{ }^{-}-\mathrm{N}$ and $\mathrm{PO}_{4}{ }^{3-}-\mathrm{P}$ were measured by spectrophotometric method using Spectroquant Cell Test (NOVA 60, Merck). The $\mathrm{pH}$ and temperature of the reactor were measured everyday using $\mathrm{pH}$ meter (Hach Company, model no. HQ40d).

The granular sludge was collected at 3 sampling port at different heights of the UAGB (Port 1: $20 \mathrm{~cm}$, Port 2: $40 \mathrm{~cm}$ and Port 3: $60 \mathrm{~cm}$ height from the bottom). Mixed liquor suspended solids (MLSS), mixed liquor volatile suspended solids (MLVSS), sludge volume index (SVI), settling velocity and zeta potential were conducted based on the methods described in Standard Methods (APHA, 1999). Particle size distribution (PSD) of granule 
sludge samples was determined using the laser particle size analysis system (Mastersizer Series 2000 supplied by Malvern Instruments Ltd., UK) with a detection range of 0.02-2000 $\mathrm{mm}$. The scattered light was detected by means of a detector that converted the signal to a size distribution based on volume. Each sample was measured three times with a standard deviation of $0.1-4.5 \%$. D (0.1) (i.e. $10 \%$ of the volume distribution was below this value) was used to describe the colloidal and fine particle fractions. The sludge granules were examined by Olympus System Microscope Model BX41 (Olympus, Japan) and the images were captured and analyzed using Image-Pro Plus software.

Based on the resistance-in-series model, fouling resistance of the G-AnMBR was determined after G-AnMBR experiments by using measurement protocol proposed by Deng et al. (2015) and applying Eqs. (1) and (2) (Choo and Lee, 1996):

$\mathrm{J}=\Delta \mathrm{P} / \mu \mathrm{R}_{\mathrm{T}}(1)$

$\mathrm{RT}=\mathrm{R}_{\mathrm{M}}+\mathrm{R}_{\mathrm{C}}+\mathrm{R}_{\mathrm{P}}(2)$

Where $\mathrm{J}$ is the permeation flux $\left(\mathrm{m}^{3} \mathrm{~m}^{-2} \mathrm{~h}^{-1}\right) ; \Delta \mathrm{P}$ is the transmembrane pressure $(\mathrm{Pa}) ; \mu$ is the dynamic viscosity of the permeate $(\mathrm{Pa} \mathrm{s}) ; \mathrm{R}_{\mathrm{T}}$ is total resistance $\left(\mathrm{m}^{-1}\right) ; \mathrm{R}_{\mathrm{M}}$ is the intrinsic membrane resistance $\left(\mathrm{m}^{-1}\right) ; \mathrm{R}_{\mathrm{C}}$ is the cake layer resistance $\left(\mathrm{m}^{-1}\right)$; and $\mathrm{R}_{\mathrm{P}}$ is the pore blocking resistance $\left(\mathrm{m}^{-1}\right)$. The linear relationship of flux $\times$ viscosity and TMP can be established by plotting the TMP curve against membrane flux $\times$ viscosity, and the gradient indicates the corresponding membrane resistance.

The extraction and analysis of EPS and SMP in the granular sludge, cake layer and mixed liquor from the G-AnMBR were based on the methods provided by Deng et al. (2014). The extracted samples were further analysed for protein $\left(E P S_{P}\right.$ and $\left.S_{M P}\right)$ and polysaccharide $\left(\right.$ EPS $_{\mathrm{C}}$ and $\mathrm{SMP}_{\mathrm{C}}$ ) concentrations, using modified Lowry method (Sigma, Australia) and Anthrone-sulfuric acid method, respectively. Foulant attached on the surface of membrane was extracted with $2 \mathrm{~L}$ of $0.4 \% \mathrm{NaOH}$ solution using a horizontal shaker for $3 \mathrm{~h}$. The extract was filtered through $1.2 \mu \mathrm{m}$ filter and filtrate was then diluted to ensure the DOC level was less than $5 \mathrm{mg} \mathrm{L}^{-1}$ before being analyzed. Size exclusion liquid chromatograph with organic carbon detector (LC-OCD), a TSK HW 50-(S) column and a $0.028 \mathrm{~mol} \mathrm{~L}^{-1}$ phosphate buffer were used to analyse the hydrophilic and hydrophobic fractions of the membrane foulant.

The extraction and quantification of six types of volatile fatty acids (VFA) in the supernatant of the mixed liquor, i.e., acetate acid, propionic acid, isobutyric acid, butyric acid, iso-valeric acid and valeric acid in the supernatant of the sludge, were conducted based on the methods provided by Banel and Zygmunt (2011) using methyl-tert-butyl ether (MTBE) for liquid-liquid extraction and gas chromatogram mass spectrometry method (GCMS TQ8040, Shimadzu, Japan) for analysis. Biogas produced was collected by a biogas sample bag and its amount was determined by a liquid displacement device. Biogas composition including $\mathrm{CH}_{4}$, $\mathrm{CO}_{2}, \mathrm{H}_{2}, \mathrm{H}_{2} \mathrm{~S}$ and $\mathrm{N}_{2}$ was determined using Geotech potable biogas analyser (Biogas 5000, Geotech, UK). All the liquid, gas and sludge samples were tested in triplicate, with an average value and standard deviation for discussion.

\section{Results and discussion}

\subsection{Organic and nutrient removal}


Organic removal efficiency over $90 \%$ was achieved in both G-AnMBRs. The EGAnMBR removed $92.6 \pm 2.3 \%$ of DOC and $91.9 \pm 1.5 \%$ of COD while $91.8 \pm 1.9 \%$ of DOC and $91.3 \pm 2.1 \%$ of COD were eliminated by the SG-AnMBR. The relatively high organic removal efficiencies could be attributed to the complete retention of all particulate and colloidal matter, and biomass by membrane. The influent COD also contained the majority of readily biodegradable COD using glucose as the sole carbon source, which contributed to the high organic removal (Martinez-Sosa et al., 2011). The EG-AnMBRs exhibited $\mathrm{NH}_{4}{ }^{+}-\mathrm{N}$ reduction at $24.2 \pm 6.3 \%$ and $\mathrm{PO}_{4}{ }^{3-}-\mathrm{P}$ elimination at $12.2 \pm 4.3 \%$ while the SG-AnMBR had similar $\mathrm{NH}_{4}{ }^{+}-\mathrm{N}(23.1 \pm 5.8 \%)$ and $\mathrm{PO}_{4}{ }^{3-}-\mathrm{P}(11.3 \pm 5.1 \%)$ removal. The low ammonia and phosphate removal efficiencies were due to the fact that nutrient removal was not expected in the anaerobic treatment. The results showed that the membrane addition methods had negligible impact on the organic and nutrient removal of G-AnMBRs.

\subsection{Comparisons of granular sludge properties}

\subsubsection{Granular sludge}

The performance of UAGB relies on its capability to form a dense granular sludge bed in the reaction region for efficient physical entrapment and biological degradation of particulate and dissolved organic substances (Seghezzo et al., 1998). The granular sludge MLSS and MLVSS concentrations in the EG-AnMBR gradually increased during operation, reaching $25.23 \mathrm{~g} \mathrm{~L}^{-1}$ and $21.78 \mathrm{~g} \mathrm{~L}^{-1}$, respectively at the end of operation on day 75 (Table 1). While for the SG-AnMBR, MLSS and MLVSS concentrations were relatively stable at $22.18 \mathrm{~g} \mathrm{~L}^{-1}$ and $17.92 \mathrm{~g} \mathrm{~L}^{-1}$, respectively when operation was terminated on day 35 . The biomass growth rate $((\Delta \mathrm{MLSS} / \Delta \mathrm{t}))$ was found at $0.050 \mathrm{~g} \mathrm{~d}^{-1}$ in the EG-AnMBR, which was higher than that of the SG-AnMBR $\left(0.022 \mathrm{~g} \mathrm{~d}^{-1}\right)$. In the case of the EG-AnMBR, hydraulics in the UAGB reactor was not influenced by the external membrane incorporation in the subsequent membrane tank. This configuration allowed the selective washout of the flocculent sludge with poor settling ability, which could lead to an increased growth of retained sludge agglomerates and granules. In this case, biodegradation of organics occurred mainly within the granules, promoting the growth of granules rather than dispersed growth of free swimming bacteria (Martin-Garcia et al., 2013). In contrast, as for the SG-AnMBR configuration, the membrane direct addition into the UAGB eliminated the selection pressure on the granules due to a nearly complete retention of small and colloidal flocs, thus resulting in the accumulation of fine sludge flocs and suspended particles inside the UAGB (Ozgun et al., 2015). In this case, the growth of dispersed sludge with poor immobilization properties could predominately take place, resulting in the bulking type of sludge formed in the SG-AnMBR and undermining granular growth.

The settling ability of the sludge determines the level of biomass retention and physical removal of particulate organics in the UAGB, and influences the fouling propensity when coupling UAGB with membrane separation. Granules from the EG-AnMBR had a better settling ability, which could be seen from the decreased SVI and increased settling velocity values compared to the seed (Table 1). At the end of the EG-AnMBR operation, SVI was found at $24.5 \mathrm{~mL} \mathrm{~g}^{-1}$ while settling velocities of granular sludge were around $14.1-28.5 \mathrm{~m} \mathrm{~h}^{-}$ ${ }^{1}$. In contrast, the SG-AnMBR contained granular sludge with higher SVI of $72.5 \mathrm{~mL} \mathrm{~g}^{-1}$ and lower settling velocity of $12.1-17.2 \mathrm{~m} \mathrm{~h}^{-1}$ than those of seed sludge and the EG-AnMBR, which revealed the settleability of granular sludge was deteriorated. Zeta potential value of the granular sludge was measured in the EG-AnMBR $(-13.1 \mathrm{mV})$, which was found higher than that in the SG-AnMBR $(-19.1 \mathrm{mV})$. Higher zeta potential suggested that the negative 
charge on the surface of the flocs could be neutralized to form larger granular sludge with better settling properties (Deng et al., 2014).

\section{Table 1}

\subsubsection{Granules}

Bhunia and Ghangrekar (2007) have defined that the required minimum granule size was $340 \mu \mathrm{m}$ with specific gravity of 1.035 . Chu and Huang (2005) have suggested granule size distribution ranging from $0.25 \mathrm{~mm}$ to $3.75 \mathrm{~mm}$ when treating sucrose- and phenolcontaining synthetic wastewaters. The reported granule size in Zhang et al. (2011) was 125$830 \mu \mathrm{m}$ while Pevere et al. (2006) recognized bioparticles with the size of $100 \mu \mathrm{m}$ or even less as anaerobic granules. In this study, granular sludge with the size larger than $100 \mu \mathrm{m}$ was defined as granules since low strength synthetic municipal wastewater was adopted as the feed for the G-AnMBRs. As can be seen from Table 2, seed sludge for both G-AnMBRs showed very high similarity in PSD, since the two systems were inoculated with sludge from the same source. However, significant differences were observed for the granular sludge PSD obtained from two systems at the end of the operation. One way shift to fine flocs was found in the SG-AnMBR, which could be due to the membrane's complete retention of fine sludge particles $(<100 \mu \mathrm{m})$ including small particles such as colloidal flocs and macromolecules of SMP, and non-settling particles in the SG-AnMBR. On the other hand, abundant larger-sized granules were developed in the EG-AnMBR. The fraction of granules $(>100 \mu \mathrm{m})$ was found around $41.9 \%$ of the total granular sludge in the SG-AnMBR, which was about half of the value obtained from the EG-AnMBR (81.4\%).

\section{Table 2}

EPS serves as an essential element for the formation of anaerobic granules, and is vital for integrating cells into large aggregates and granules and preserving the sound structure of granules. The lower percentage of granules in the SG-AnMBR also indicated that granules segregation occurred in the granular sludge bed. The SG-AnMBR contained significantly lower total EPS concentration at $6.1 \pm 1.2 \mathrm{mg}(\mathrm{g} \text { MLVSS })^{-1}$ with both protein and polysaccharides amounts of EPS decreased by $83.3 \pm 5.2 \%$ and $76.3 \pm 4.2 \%$, as compared to those of the seed sludge (total EPS, EPS, EPS $_{C}$ at $23.5 \pm 3.3,17.2 \pm 2.3,5.3 \pm 1.2 \mathrm{mg}$ (g

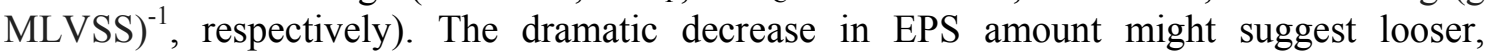
scattered and weaker structures of sludge granules in the SG-AnMBR, meaning possible granule fragmentation and decrease in PSD, and SMP increase in mixed liquor (Ozgun et al.,

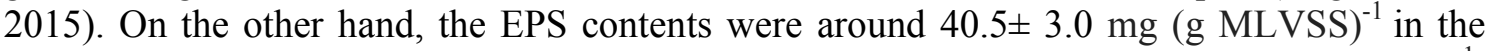
EG-AnMBR, in which EPS ${ }_{P}$ and EPS $_{C}$ were $31.8 \pm 2.1$ and $7.5 \pm 1.2 \mathrm{mg}(\mathrm{g} \mathrm{MLVSS})^{-1}$, respectively. The higher contents of EPS increased the electrostatic interactions between the microbial biomass and the polymeric material and therefore, rapidly increased the granular sludge particle size and promoted the formation of granules. The total SMP contents $(38.5 \pm$ $2.3 \mathrm{mg}\left(\mathrm{g} \mathrm{MLVSS}^{-1}\right)$ of the SG-AnMBR were found 5.6 times higher than those of the EGAnMBR $\left(5.8 \pm 1.2 \mathrm{mg}(\mathrm{g} \mathrm{MLVSS})^{-1}\right)$. Much lower SMP values of the EG-AnMBR confirmed that the dominant fraction of the proteins and polysaccharides existed as the part of the anaerobic granules as their lower amounts detected in the soluble form as SMP.

\subsection{Membrane fouling behaviour}




\subsubsection{TMP development}

Fig. 1 demonstrated the TMP profiles in both EG-AnMBR and SG-AnMBR. Obvious difference was observed in TMP increase from two distinctive G-AnMBRs. For the EGAnMBR, the gradual increase in TMP was found over the operation period. The increase in TMP was found up to $30 \mathrm{kPa}$ on day 75, and the fouling rate was approximately $0.4 \mathrm{kPa} \mathrm{d}^{-1}$. On the contrary, the SG-AnMBR initially presented a gradual increase in TMP from $2.0 \mathrm{kPa}$ to $11.2 \mathrm{kPa}$ until day 24. A sudden TMP jump to $16 \mathrm{kPa}$ was observed on day 25 , and TMP reached $32.0 \mathrm{kPa}$ after 35 days. The averaged fouling rate for the SG-AnMBR was around 0.9 $\mathrm{kPa} \mathrm{d}^{-1}$, which was 2.25 times to the corresponding value obtained from the EG-AnMBR.

\section{Fig. 1}

\subsubsection{EPS and SMP of the mixed liquor}

In this study, SMP and EPS in the mixed liquor of SG-AnMBR (settling zone) and EGAnMBR (membrane tank) were monitored, in order to explain the relationship between the property of mixed liquor and membrane fouling as membrane was directly immersed in the mixed liquor. Figs. 2 and 3 demonstrated the SMP and EPS concentrations of the mixed liquor and their polysaccharides $\left(\mathrm{SMP}_{\mathrm{C}}, \mathrm{EPS}_{\mathrm{C}}\right)$ and protein contents $\left(\mathrm{SMP}_{\mathrm{P}}, \mathrm{EPS}_{\mathrm{P}}\right)$ from both G-AnMBRs at different designated TMP values. It was obvious that EPS concentrations of both systems increased over the operation period. Prior to the sudden TMP jump (15 kPa), EPS (total EPS, EPS and $_{\text {EPS }}$ ) were at low values and presented minor difference in both G-AnMBRs. At TMP of $15 \mathrm{kPa}$, noticeable differences of EPS levels between the SGAnMBR and EG-AnMBR were observed. A notable increase in EPS was found in the SGAnMBR (36.1 $\mathrm{mg} \mathrm{L}^{-1}$ ), while EPS $\mathrm{P}_{\mathrm{P}}$ and $\mathrm{EPS}_{\mathrm{C}}$ rose to $22.4 \mathrm{mg} \mathrm{L}^{-1}$ and $12.5 \mathrm{mg} \mathrm{L}^{-1}$. In contrast, the EG-AnMBR possessed lower EPS at $25.8 \mathrm{mg} \mathrm{L}^{-1}$, with $\mathrm{EPS}_{\mathrm{P}}$ and $\mathrm{EPS}_{\mathrm{C}}$ at 16.8 and $7.5 \mathrm{mg}$ $\mathrm{L}^{-1}$. At the time when TMP reached $30 \mathrm{kPa}$, total EPS, EPS $\mathrm{P}_{\mathrm{P}}$ and $\mathrm{EPS}_{\mathrm{C}}$ in the SG-AnMBR climbed up to the highest values of $62.2,42.5$, and $19.3 \mathrm{mg} \mathrm{L}^{-1}$, respectively, which were approximately 1.8 times of EPS values from the EG-AnMBR $\left(33.4,22.1\right.$, and $10.5 \mathrm{mg} \mathrm{L}^{-1}$, respectively). Higher concentrations of EPS in the mixed liquor of the SG-AnMBR were possibly ascribed to higher MLSS concentration in the settling zone of UAGB. The averaged MLSS in the SG-AnMBR was observed at $138.5 \pm 8.89 \mathrm{mg} \mathrm{L}^{-1}$ which was approximately three times higher than those of the EG-AnMBR $\left(45.2 \pm 7.18 \mathrm{mg} \mathrm{L}^{-1}\right)$. The MLSS concentration peaked at $180.2 \pm 9.12 \mathrm{mg} \mathrm{L}^{-1}$ in the SG-AnMBR while the EG-AnMBR had MLSS of $50.2 \pm 6.18 \mathrm{mg} \mathrm{L}^{-1}$ when TMP reached $30 \mathrm{kPa}$. Much higher MLSS in the SGAnMBR was mainly attributed to membrane's complete retention of dispersed sludge with poor immobilization properties under infinite sludge retention time (SRT). The deterioration of the sludge settling capacity also encouraged inefficient solid entrapment of the sludge bed and hence promoted the accumulation of small and colloidal flocs in the mixed liquor, and the accumulation of small particles in the lumen (Ozgun et al., 2015).

\section{Fig. 2}

Fig. 3

With respect to SMP production in both G-AnMBRs, the EG-AnMBR showed very stable SMP concentration at $26.7 \pm 1.1 \mathrm{mg} \mathrm{L}^{-1}$ while no obvious variation was observed in $\operatorname{SMP}_{\mathrm{P}}\left(17.0 \pm 0.7 \mathrm{mg} \mathrm{L}^{-1}\right)$ and $\operatorname{SMP}_{\mathrm{C}}\left(8.9 \pm 0.3 \mathrm{mg} \mathrm{L}^{-1}\right)$. The SG-AnMBR showed wide fluctuations of SMP concentrations between 36.2 and $56.9 \mathrm{mg} \mathrm{L}^{-1}$, and SMP levels of the SG- 
AnMBR were substantially larger than those of the EG-AnMBR at all designated TMPs. The results revealed that both SMP and EPS in the SG-AnMBR were responsible for faster fouling period with rapid TMP development (Miyoshi et al., 2012; Prado et al., 2017). EPS clog the membrane pores, accelerating the formation of a strongly attached fouling layer on the membrane surface due to their multiple functions including cell aggregation, formation of a protective barrier and retention of water and adhesion to surfaces (Salazar-Pelaez et al., 2011a; Sun et al., 2016). On the other hand, accumulation of SMP in the pores and/or on the membrane surface causes pores blockage and a gel layer formation, limiting membrane permeability (Deng et al., 2014; Zuthi et al., 2013).

\subsubsection{Analysis of fouling resistance, cake layer and foulant}

G-AnMBR operation was terminated after TMP reached $30 \mathrm{kPa}$, and membranes were taken out for physical and chemical cleaning. The fouling resistance was calculated based on the resistance-in-series model and the results were shown in Table 3. Total hydraulic resistance $\left(R_{T}\right)$ was found higher in the SG-AnMBR $\left(20.7 \times 10^{13} \mathrm{~m}^{-1}\right)$ as compared to that of the EG-AnMBR $\left(13.4 \times 10^{13} \mathrm{~m}^{-1}\right)$. Pore blocking $\left(\mathrm{R}_{\mathrm{P}}\right)$ only contributed to a small portion of the total resistance. $R_{P}$ of the SG-AnMBR $\left(1.5 \times 10^{13} \mathrm{~m}^{-1}\right)$ accounted for $7.1 \%$ of $R_{T}$, while the EG-AnMBR had $R_{P}$ at $0.7 \times 10^{13} \mathrm{~m}^{-1}$, corresponding to $5.4 \%$ of $\mathrm{R}_{\mathrm{T}}$. As for both G-AnMBRs, cake layer resistance $\left(R_{C}\right)$ was responsible for over $92 \%$ of total resistance. Liu et al. (2012) also reported that total filtration resistance was mainly governed by cake filtration resistance (over $98 \%$ of $\mathrm{R}_{\mathrm{T}}$ ). The results suggested the significance of minimizing the cake formation in G-AnMBRs, in order to increase membrane filtration efficiency. Cake layer resistance of the SG-AnMBR was found 50\% higher than that of the EG-AnMBR. Lin et al. (2010) reported D (0.1), meaning the colloidal and fine particle fractions, had a significant negative effect on the cake formation rate. The D $(0.1)$ of the SG-AnMBR was $69.1 \mu \mathrm{m}$, which was approximately 2 times to that of the EG-AnMBR $(35.2 \mu \mathrm{m})$, and could be partly responsible for the higher cake fouling resistance in the SG-AnMBR.

Since the cake layer contributed to the dominant fraction of the total fouling resistance, the compositions of EPS and SMP of the cake layer on the membrane surface were further analysed (Table 3). Higher concentration in EPSP was found in the SG-AnMBR (11.7 mg (g

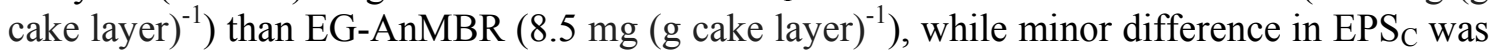
observed in both G-AnMBRs. EPS $\mathrm{P}_{\mathrm{P}}$ excreted from the anaerobic microbes exert an impact on the cake resistance via filling the void spaces between the particles in the cake leading to a severe reduction of permeate flux (Chu et al., 2005). Instead of EPS $S_{P}$, structure collapse was responsible for cake filtration resistance (Liu et al., 2012). Factors that promoted the compactness and dewatering of the membrane cake layer were also responsible for cake resistance in a long-term operation. With regards to SMP concentration of the cake layer, the SG-AnMBR exhibited higher $\mathrm{SMP}_{\mathrm{P}}$ and $\mathrm{SMP}_{\mathrm{C}}$ concentrations of 18.6 and $6.5 \mathrm{mg}$ (g cake

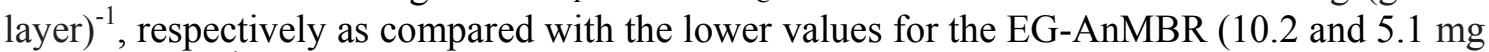
$\left.\left(g_{\text {c cake layer }}\right)^{-1}\right)$. The accumulation of $\mathrm{SMP}_{\mathrm{P}}$ could change the surface charge and morphology of the membrane, promoting the adhesion and growth of sludge flocs as cake layer (Deng et al., 2014; Liu et al., 2012). Furthermore, the build-up of SMP ${ }_{C}$ could result in irreversible fouling by forming a thin gel layer on the membrane surface (Deng et al., 2015). Results implied that $\mathrm{EPS}_{\mathrm{P}}, \mathrm{SMP}_{\mathrm{P}}$ and $\mathrm{SMP}_{\mathrm{C}}$ were the main contributors to the higher $\mathrm{R}_{\mathrm{C}}$ in the SGAnMBR. Under higher TMP, higher drag force from the permeate pump enhanced formation of cake layer by exacerbating the accumulation of EPS $S_{P}$ and SMP on the surface of the membrane. Greater amount of sludge cake on membrane surface could promote cell lysis or 
endogenous decay at the bottom cake layer, which in turn led to more EPS $\mathrm{P}_{\mathrm{P}}$ and SMP released (Deng et al. 2014).

\section{Table 3}

The fractionation of organic matter in the foulant by LC-OCD analysis provides vital information for the understanding of fundamentals of the membrane fouling. According to Fig. 4, the biopolymers showed the greatest difference between two G-AnMBRs, with 14.6 $\mathrm{mg} \mathrm{L}^{-1}$ in the SG-AnMBR and $6.9 \mathrm{mg} \mathrm{L}^{-1}$ in the EG-AnMBR. In fact, Yue et al. (2015) and Johir et al. (2012) both recognized biopolymers as the major foulants responsible for membrane fouling in the aerobic MBR and AnMBR operations. Higher concentration of biopolymers might suggest hydrophilic layers build-up on the membrane surface in the SGAnMBR (Hong et al. 2012). LC-OCD also indicated the SG-AnMBR possessed higher amount of building blocks and low molecular weight (LMW) neutrals and acids $\left(6.3 \mathrm{mg} \mathrm{L}^{-1}\right.$, $9.7 \mathrm{mg} \mathrm{L}^{-1}$, respectively) than those in the EG-AnMBR (4.6 $\mathrm{mg} \mathrm{L}^{-1}, 5.9 \mathrm{mg} \mathrm{L}^{-1}$, respectively). Building blocks and LMW neutrals and acids were the influential factors affecting fouling as their assemblage could promote biopolymers formation on the membrane surface, exacerbating fouling propensity (Aryal et al., 2009). Last but not least, minor difference in the concentration of humic substances was observed between two G-AnMBRs, indicating the impact of humic substances on the fouling could be neglected in this study.

\section{Fig. 4}

\subsection{VFA and biogas production}

VFA is regarded as the most vital process performance indicator for G-AnMBR operation since it not only serves as the essential intermediary compounds in the metabolic pathway of methane fermentation but also profoundly affects $\mathrm{pH}$ dynamics in the system (Ji et al., 2015). If presented in high concentration, VFA accumulation in G-AnMBRs can result in significant $\mathrm{pH}$ drop and microbial stress, particularly for methane-producing bacteria, ultimately resulting in reactor acidification and even failure (Chen et al., 2008; Chen et al., $2016 \mathrm{~b})$. The VFA of the mixed liquor, including acetic acid $\left(\mathrm{C}_{2}\right)$, propionic acid $\left(\mathrm{C}_{3}\right)$, isobutyric acid $\left(\mathrm{i}-\mathrm{C}_{4}\right)$, butyric acid $\left(\mathrm{C}_{4}\right)$, iso-valeric acid $\left(\mathrm{i}-\mathrm{C}_{5}\right)$ and valeric acid $\left(\mathrm{C}_{5}\right)$ were monitored in this study. According to Table $4, \mathrm{C}_{2}$ accounted for the dominant fraction of VFA $(97.0 \%)$ in the mixed liquor of the EG-AnMBR, with concentration as low as $5.2 \pm 1.1$ $\mathrm{mg} \mathrm{L}{ }^{-1}$. Only very low amount of $\mathrm{C}_{3}\left(0.2 \pm 0.3 \mathrm{mg} \mathrm{L}^{-1}\right)$ was found randomly while $\mathrm{C}_{4}-\mathrm{C}_{5}$ was not detected. This revealed that the EG-AnMBR was rarely encountered with VFA accumulation and reactor acidification over the operation time.

\section{Table 4}

On the other hand, the SG-AnMBR possessed much higher concentration of VFA at 25.3 $\pm 4.9 \mathrm{mg} \mathrm{L}^{-1}$, which was 4 times more than the corresponding value in the CG-AnMBR. $\mathrm{C}_{2}$ accounted for the major fraction $(65.8 \%)$ in the VFA of the mixed liquor. $\mathrm{C}_{3}-\mathrm{C}_{5}$ was also detected although their concentrations were lower than that of acetic acid. The higher concentration of VFA could be related to VFA release from the granule fragmentation, since the elimination of hydraulic selection pressure undermined the integrity of sound granules in the submerged configuration. A low VFA concentration (below $5 \mathrm{mg} \mathrm{L}^{-1}$ as acetic acid) was found from both G-AnMBRs permeate, suggesting G-AnMBR system was capable of eliminating most of the biodegradable organic material in the wastewater. 
Biogas produced from the G-AnMBRs is a competitive advantage against the aerobic MBRs. Similar biogas production was observed at around $650 \mathrm{~mL} \mathrm{~d}^{-1}$ and $666 \mathrm{~mL} \mathrm{~d}^{-1}$ from the EG-AnMBR and SG-AnMBR. Biogas production was not profoundly affected, even though SG-AnMBR was encountered with VFA accumulation to some extent. Stable methane and carbon dioxide composition in the biogas were around 69.7 and $26.9 \%$ in the EGAnMBR, while the SG-AnMBR had 68.5 and $26.0 \%$, respectively. Tracable $\mathrm{H}_{2}$ with 3-10 ppm was detected in the biogas from both G-AnMBRs. The EG-AnMBR achieved methane yield of $160.6 \pm 5.6 \mathrm{~mL} \mathrm{CH}_{4}$ (STP) $\left(\mathrm{g} C O D\right.$ removed) ${ }^{-1}$ (volume of methane produced per $\mathrm{g}$ $\mathrm{COD}_{\text {removed }}$ at $0{ }^{\circ} \mathrm{C}$ Standard Temperature and 1 atm Pressure), which was almost the same to the value from the SG-AnMBR $\left(161.3 \pm 4.6 \mathrm{~mL} \mathrm{CH}_{4}\right.$ (STP) $\left.(\mathrm{g} \mathrm{COD} \text { removed })^{-1}\right)$. Methane yield from two G-AnMBRs represented only about $50 \%$ of the optimal theoretical value at $20^{\circ} \mathrm{C}$

$\left(317.6 \pm 4.6 \mathrm{~mL} \mathrm{CH}_{4}\right.$ (STP) $\left.\left(\mathrm{g} \mathrm{COD}_{\text {removed }}\right)^{-1}\right)$. Nearly half of the removed COD was lost in the form of dissolved methane in the permeate. Galib et al. (2016) revealed that methane loss in the aqueous phase was significant and could be up to $58 \%$ of the total methane produced from AnMBRs. While Sanchez-Ramirez et al. (2015) also suggested a significant dissolved methane concentration, accounting for $20-40 \%$ of methane in the produced biogas, could be lost in the AnMBR effluent. Furthermore, when using AnMBR for the treatment of municipal wastewater under low temperatures (i.e. $15-20^{\circ} \mathrm{C}$ ), the release of this dissolved methane into atmosphere could be a more critical issue as greater amount of methane could be dissolved in the permeate under the lower temperature and emitted to the atmosphere (Pretel et al., 2016). Hence, quantifying and recovering dissolved methane in the permeate would be of great significance in the future research since greenhouse gas potential of dissolved methane is significant and may impact the environmental sustainability of G-AnMBRs.

\section{Conclusion}

In this study, external and submerged granular anaerobic membrane bioreactors (GAnMBRs) were operated in parallel treating municipal wastewater, in order to investigate differences with respect to overall performance of two different configurations of GAnMBRs. Negligible differences were noticed in terms of the organic removal and methane yield although VFA accumulation exhibited in the SG-AnMBR. Deteriorated granular sludge properties were found in the SG-AnMBR with granules fragmentation, reduced granules EPS content and settleability. The SG-AnMBR demonstrated higher fouling propensity, which could be attributed to higher concentrations of SMP and EPS in mixed liquor, much higher cake layer resistance, and more deposition of EPS $P$ and SMP in the cake layer. The characterization of foulant organics demonstrated that biopolymers were the major foulants followed by LMW neutrals and acids and building blocks. The results proved that the EGAnMBR was a more promising configuration for municipal wastewater treatment due to the better granular sludge quality and prolonged operation time.

\section{References}

APHA, 1999. Standard Methods for the Examination of Water and Wastewater. American Public Health Association, Washington.

Aryal, R., Legegue, J., Vigneswaran, S., Kandasamy, J., Heran, M., Grasmick, A., 2009. Identification and characterisation of biofilm formed in membrane bioreactor. Sep. Purif. Technol. 67, 86-94. 
Banel, A., Zygmunt, B., 2011. Application of gas chromatography-mass spectrometry preceded by solvent extraction to determine volatile fatty acids in wastewater of municipal, animal farm and landfill origin. Water Sci. Technol. 63, 590-597.

Bhunia, P., Ghangrekar, M.M., 2007. Required minimum granule size in UASB reactor and characteristics variation with size. Bioresour. Technol. 98, 994-999.

Chen, Y., Cheng, J.J., Creamer, K.S., 2008. Inhibition of anaerobic digestion process: A review. Bioresour. Technol. 99, 4044-4064.

Chen, C., Guo, W.S., Ngo, H.H., 2016a. Advances in granular growth anaerobic membrane bioreactor (G-AnMBR) for low strength wastewater treatment, Journal of Energy and Environmental Sustainability 1, 77-83.

Chen, C., Guo, W.S., Ngo, H.H., Lee, D.J., Tung, K.L., Jin, P.K., Wang, J., Wu. Y., 2016 b. Challenges in biogas production from anaerobic membrane bioreactors. Renew. Energ. 98, $120-134$.

Choo, K.H., Lee, C.H., 1996. Membrane fouling mechanisms in the membrane coupled anaerobic bioreactor. Water Res. 30, 1771-1780.

Chou, H.H., Huang, J.S., 2005. Comparative granule characteristics and biokinetics of sucrose fed and phenol fed UASB reactors. Chemosphere 59, 107-116.

Chu, L.B., Yang, F.L., Zhang, X.W., 2005. Anaerobic treatment of domestic wastewater in a membrane-coupled expanded granular sludge bed (EGSB) reactor under moderate to low temperature. Process Biochem. 40, 1063-70.

Deng, L.J., Guo, W.S., Ngo, H.H., Zhang, J., Liang, S., Xia, S., Zhang, Z., Li, J., 2014. A comparison study on membrane fouling in a sponge-submerged membrane bioreactor and a conventional membrane bioreactor. Bioresour. Technol. 165, 69-74.

Deng, L.J., Guo, W.S., Ngo, H.H., Zuthi, M.F.R., Zhang, J., Liang, S., Li, J.X., Wang, J., Zhang, X.B., 2015. Membrane fouling reduction and improvement of sludge characteristics by bioflocculant addition in submerged membrane bioreactor. Sep. Purif. Technol. 156, 450-458.

Galib, M., Elbeshbishy, E., Reid, R., Hussain, A., Lee, H., 2016. Energy-positive food wastewater treatment using an anaerobic membrane bioreactor (AnMBR). J. Environ. Manage. 182, 477-485.

Gimenez, J.B., Marti, N., Ferrer, J., Seco, A., 2012. Methane recovery efficiency in a submerged anaerobic membrane bioreactor (SAnMBR) treating sulphate-rich urban wastewater: Evaluation of methane losses with the effluent. Bioresour. Technol. 118, 6772.

Herrera-Robledo, M., Cid-Leon, D.M., Morgan-Sagastume, J.M., Noyola, A., 2011. Biofouling in an anaerobic membrane bioreactor treating municipal sewage. Sep. Purif. Technol. 81, 49-55.

Herrera-Robledo, M., Morgan-Sagastume, J.M., Noyola, A., 2010. Biofouling and pollutant removal during long-term operation of an anaerobic membrane bioreactor treating municipal wastewater. Biofouling 26, 23-30.

Hong, S., Aryal, R.,Vigneswaran, S., Johir, M.A.H., Kandasamy, J., 2012. Influence of hydraulic retention time on the nature of foulant organics in a high rate membrane bioreactor. Desalination 287, 116-122.

Huang, Y.T., Huang, T.H., Yang, J.H., Damodar, R.A., 2012. Identifications and characterizations of proteins from fouled membrane surfaces of different materials. Int. Biodeterior. Biodegrad. 66, 47-52.

Ji, J.Y., Wang, H., Zheng, P., Xing, Y.J., Zheng, X.L., 2015. Early-warning on the performance of novel high-rate anaerobic bioreactor. Sep. Purif. Technol. 156, 103-107. 
Johir, M.A.H., Vigneswaran, S., Sathasivan, A., Kandasamy, J., Chang, C.Y., 2012. Effects of organic loading rate on organic matter and foulant characteristics in membrane bio-reactor. Bioresour. Technol. 113, 154-160.

Kim, J., Shin, J., Kim, H., Lee, J.Y., Yoon, M., Won, S., Lee, B.C., Song, K.G., 2014. Membrane fouling control using a rotary disk in a submerged anaerobic membrane sponge bioreactor. Bioresour. Technol. 172, 321-327.

Kola, A., Ye, Y., Le-Clech, P., Chen, V., 2014. Transverse vibration as novel membrane fouling mitigation strategy in anaerobic membrane bioreactor applications. J. Membr. Sci. 455, 320-329.

Lin, H.J., Xie, K., Mahendran, B., Bagley, D.M., Leung, K.T., Liss, S.N., Liao, B.Q., 2010. Factors affecting sludge cake formation in a submerged anaerobic membrane bioreactor. J. Membr. Sci. 361 126-134.

Liu, Y., Liu, H.N., Cui, L., Zhang, K.S., 2012. The ratio of food-to-microorganism (F/M) on membrane fouling of anaerobic membrane bioreactors treating low-strength wastewater. Desalination 297, 97-103.

Liu, Y., Zhang, K.S., Bakke, R., Li, C.M., Liu, H.N., 2013. Membrane installation for enhanced upflow anaerobic sludge blanket (UASB) performance. J. Biosci. Bioeng. 116, 357-361.

Martinez-Sosa, D., Helmreich, B., Netter, T., Paris, S., Bischof, F., 2011. Anaerobic submerged membrane bioreactor (AnMBR) for municipal wastewater treatment under mesophilic and psychrophilic temperature conditions. Bioresour. Technol. 102, 1037710385.

Martin-Garcia, I., Mokosch, M., Soares, A., Pidou, M., Jefferson, B., 2013. Impact of reactor configuration on the performance of anaerobic MBRs: Treatment of settled sewage in temperature climates. Water Res. 47, 4853-4860.

Martin-Garcia, I., Mokosch, M., Soares, A., Pidou, M., Le-Clech, P., Judd, S.J., McAdam, E.J., Jefferson, B., 2011. Impact of membrane configuration on fouling in anaerobic membrane bioreactors. J. Membr. Sci. 382, 41-49.

Miyoshi, T., Aizawa, T., Kimura, K., Watanabe, Y., 2012. Identification of proteins involved in membrane fouling in membrane bioreactors (MBRs) treating municipal wastewater. Int. Biodeterior. Biodegrad. 75, 15-22.

Mnif, S., Zayen, A., Karray, F., Bru-Adan, V., Loukil, S., Godon, J.J., Chamkha, M., Sayadi, S., 2012. Microbial population changes in anaerobic membrane bioreactor treating landfill leachate monitored by single-strand conformation polymorphism analysis of $16 \mathrm{~S}$ rDNA gene fragments. Int. Biodeterior. Biodegrad. 73, 50-59.

Ng, K.K., Shi, X.Q., Tang, M., Ng, H.Y., 2014. A novel application of anaerobic bioentrapped membrane reactor for the treatment of chemical synthesis-based pharmaceutical wastewater. Sep. Purif. Technol. 132, 71-78.

Ozgun, H., Gimenez, J.B., Ersahin, M.E., Tao, Y., Spanjers, H., van Lier, J.B., 2015. Impact of membrane addition for effluent extraction on the performance and sludge characteristics of upflow anaerobic sludge blanket reactors treating municipal wastewater. J. Membr. Sci. 479, 95-104.

Prado, M., Borea, L., Cesaro, A., Liu, H.Z., Naddeo, V., Belgiorno, V., Ballesteros, J.F., 2017. Removal of emerging contaminant and fouling control in membrane bioreactors by combined ozonation and sonolysis. Int. Biodeterior. Biodegrad. 119, 577-586.

Pevere, A., Guibaud, G., Hullebusch, van E., Lens, P., Baudu, M., 2006. Viscosity evolution of anaerobic granular sludge. Biochem. Eng. J. 27, 315-322.

Pretel, R., Monino, P., Robles, A., Ruano, M.V., Seco, A., Ferrer, J., 2016. Economic and environmental sustainability of an AnMBR treating urban wastewater and organic fraction of municipal solid waste. J. Environ. Manage. 179, 83-92. 
Salazar-Pelaez, M.L., Morgan-Sagastume, J.M., Noyola, A., 2011a. Influence of hydraulic retention time on fouling in a UASB coupled with an external ultrafiltration membrane treating synthetic municipal wastewater. Desalination 277, 164-170.

Salazar-Pelaez, M.L., Morgan-Sagastume, J.M., Noyola, A., 2011b. Influence of hydraulic retention time on UASB post-treatment with UF membranes. Water Sci. Technol. 64, 2299-2305.

Saleem, M., Alidardi, L., Lavagnolo, M.C., Cossu, R., Spagni, A., 2016. Effect of filtration flux on the development and operation of a dynamic membrane for anaerobic wastewater treatment. J. Environ. Manage. 188, 459-465.

Sanguanpak, S., Chiemchaisri, C., Chiemchaisri, W., Yamamoto, K., 2015. Influence of operating $\mathrm{pH}$ on biodegradation performance and fouling propensity in membrane bioreactors for landfill leachate treatment. Int. Biodeterior. Biodegrad. 102, 64-72.

Seghezzo, L., Zeeman, G., van Lier, J.B., Hamelers, H.V.M., Lettinga, G., 1998. A review: the anaerobic treatment of sewage in UASB and EGSB reactors. Bioresour. Technol. 65, 175-190.

Sanchez-Ramirez, J.E., Seco, A., Ferrer, J., Bouzas, A., Garcia-Usach, F., 2015. Treatment of a submerged anaerobic membrane bioreactor (SAnMBR) effluent by an activated sludge system: The role of sulphide and thiosulphate in the process. J. Environ. Manage. 147, 213-218.

Sun, Y.M., Fang, Y.Y., Liang, P., Huang, X., 2016. Effects of online chemical cleaning on removing biofouling and resilient microbes in a pilot membrane bioreactor. Int. Biodeterior. Biodegrad. 112, 119-127.

Yue, X.D., Koh, Y.K.K., Ng, H.Y., 2015. Effects of dissolved organic matters (DOMs) on membrane fouling in anaerobic ceramic membrane bioreactors (AnCMBRs) treating domestic wastewater. Water Res. 86, 96-107.

Zhang, Y.B., An, X.L., Quan, X., 2011. Enhancement of sludge granulation in a zero valence iron packed anaerobic reactor with a hydraulic circulation. Process Biochem. 46, 471-476.

Zuthi, M.F.R., Ngo, H.H., Guo, W.S., Zhang, J., Liang, S., 2013. A review towards finding a simplified approach for modelling the kinetics of the soluble microbial products (SMP) in an integrated mathematical model of membrane bioreactor (MBR). Int. Biodeterior. Biodegrad. 85, 466-473. 


\section{Table 1.}

Comparision of sludge characteristics of inoculated sludge, granular sludge from G-AnMBRs when operation was terminated.

\begin{tabular}{lccccc}
\hline \multicolumn{1}{c}{ Sludge types } & $\begin{array}{c}\text { MLSS } \\
\left(\mathrm{g} \mathrm{L}^{-1}\right)\end{array}$ & $\begin{array}{c}\text { MLVSS } \\
\left(\mathrm{g} \mathrm{L}^{-1}\right)\end{array}$ & $\begin{array}{c}\text { SVI } \\
\left(\mathrm{mL} \mathrm{g}^{-1}\right)\end{array}$ & $\begin{array}{c}\text { Settling } \\
\text { velocity }\left(\mathrm{m} \mathrm{h}^{-1}\right)\end{array}$ & $\begin{array}{c}\text { Zeta-potential } \\
(\mathrm{mV})\end{array}$ \\
\hline $\begin{array}{l}\text { Seed sludge } \\
(\text { EG-AnMBR })\end{array}$ & $21.48 \pm 0.98$ & $17.58 \pm 1.25$ & $38.8 \pm 3.1$ & $17.5-25.4$ & $-17.5 \pm 1.3$ \\
$\begin{array}{l}\text { Seed sludge } \\
\text { (SG-AnMBR) }\end{array}$ & $21.41 \pm 1.12$ & $17.42 \pm 1.34$ & $37.5 \pm 2.9$ & $18.4-25.9$ & $-17.9 \pm 2.1$ \\
$\begin{array}{l}\text { Granular sludge } \\
\text { (EG-AnMBR) }\end{array}$ & $25.23 \pm 1.19$ & $21.78 \pm 1.08$ & $24.5 \pm 1.9$ & $14.1-28.5$ & $-13.1 \pm 1.8$ \\
$\begin{array}{l}\text { Granular sludge } \\
\text { (SG-AnMBR) }\end{array}$ & $22.18 \pm 0.78$ & $17.92 \pm 0.98$ & $72.5 \pm 7.9$ & $12.1-17.2$ & $-19.1 \pm 1.7$ \\
\hline
\end{tabular}

\section{Table 2.}

Particle size distribution of seed sludge and granular sludge from G-AnMBRs.

\begin{tabular}{lcccc}
\hline $\begin{array}{c}\text { Particle size } \\
\text { distribution }\end{array}$ & $\begin{array}{c}\text { Seed sludge } \\
\text { (EG-AnMBR) }\end{array}$ & $\begin{array}{c}\text { Seed sludge } \\
\text { (SG-AnMBR) }\end{array}$ & $\begin{array}{c}\text { Granular sludge } \\
\text { (EG-AnMBR) }\end{array}$ & $\begin{array}{c}\text { Granular sludge } \\
\text { (SG-AnMBR) }\end{array}$ \\
\hline$<50 \mu \mathrm{m}$ & $14.3 \%$ & $12.5 \%$ & $5.4 \%$ & $25.9 \%$ \\
$50-100 \mu \mathrm{m}$ & $29.1 \%$ & $28.3 \%$ & $13.2 \%$ & $33.2 \%$ \\
$100-300 \mu \mathrm{m}$ & $39.2 \%$ & $42.3 \%$ & $53.8 \%$ & $36.5 \%$ \\
$300-500 \mu \mathrm{m}$ & $9.4 \%$ & $8.9 \%$ & $14.2 \%$ & $4.2 \%$ \\
$500-1000 \mu \mathrm{m}$ & $7.2 \%$ & $7.3 \%$ & $10.5 \%$ & $3.4 \%$ \\
$>1000 \mu \mathrm{m}$ & $0.8 \%$ & $0.7 \%$ & $2.9 \%$ & $0.8 \%$ \\
\hline
\end{tabular}




\section{Table 3.}

Fouling resistance distribution and cake layer analysis of G-AnMBRs at the end of the operation.

\begin{tabular}{llll}
\hline Reactors & & EG-AnMBR & SG-AnMBR \\
\hline \multirow{2}{*}{$\begin{array}{lll}\text { Fouling } \\
\text { resistance }\end{array}$} & $\mathrm{R}_{\mathrm{M}}\left(\times 10^{11} \mathrm{~m}^{-1}\right)$ & $8.9 \pm 1.2(0.7 \%)$ & $9.1 \pm 1.8(0.4 \%)$ \\
distribution & $\mathrm{R}_{\mathrm{C}}\left(\times 10^{13} \mathrm{~m}^{-1}\right)$ & $0.7 \pm 0.2(5.4 \%)$ & $1.5 \pm 0.4(7.1 \%)$ \\
& $\mathrm{R}_{\mathrm{T}}\left(\times 10^{13} \mathrm{~m}^{-1}\right)$ & $12.6 \pm 2.5(93.9 \%)$ & $19.1 \pm 2.8(92.5 \%)$ \\
\hline $\begin{array}{l}\text { Cake layer } \\
\text { compositions }\end{array}$ & $\mathrm{EPS}_{\mathrm{P}}$ & $8.5 \pm 1.5$ & $20.7 \pm 5.1(100 \%)$ \\
$(\mathrm{mg}(\mathrm{g}$ cake & $\mathrm{SMP}_{\mathrm{P}}$ & $3.7 \pm 1.3$ & $11.7 \pm 2.2$ \\
layer $\left.)^{-1}\right)$ & $\mathrm{SMP}_{\mathrm{C}}$ & $5.1 \pm 0.8$ & $3.8 \pm 0.9$ \\
\hline
\end{tabular}

Table 4.

VFA concentrations of the mixed liquor from the EG-AnMBR and SG-AnMBR.

\begin{tabular}{|c|c|c|}
\hline \multirow[t]{2}{*}{ VFA } & EG-AnMBR & SG-AnMBR \\
\hline & $\left(\mathrm{mg} \mathrm{L}^{-1}\right)$ & $\left(\mathrm{mg} \mathrm{L}^{-1}\right)$ \\
\hline $\mathrm{C}_{2}{ }^{\mathrm{a}}$ & $5.2 \pm 1.1(97.0 \%)^{h}$ & $16.6 \pm 2.5(65.8 \%)$ \\
\hline $\mathrm{C}_{3}{ }^{\mathrm{b}}$ & $0.2 \pm 0.3(3.0 \%)$ & $1.3 \pm 0.9(5 \%)$ \\
\hline $\mathrm{i}-\mathrm{C}_{4}{ }^{\mathrm{c}}$ & 0 & $1.7 \pm 1.3(6.9 \%)$ \\
\hline $\mathrm{C}_{4}{ }^{\mathrm{d}}$ & 0 & $1.5 \pm 1.1(5.8 \%)$ \\
\hline $\mathrm{i}-\mathrm{C}_{5}{ }^{\mathrm{e}}$ & 0 & $1.7 \pm 3.0(6.6 \%)$ \\
\hline $\mathrm{C}_{5}{ }^{\mathrm{f}}$ & 0 & $2.5 \pm 0.9(10.0 \%)$ \\
\hline $\mathrm{V}_{\mathrm{T}}^{\mathrm{g}}$ & $5.4 \pm 1.1(100 \%)$ & $25.3 \pm 4.9(100 \%)$ \\
\hline
\end{tabular}




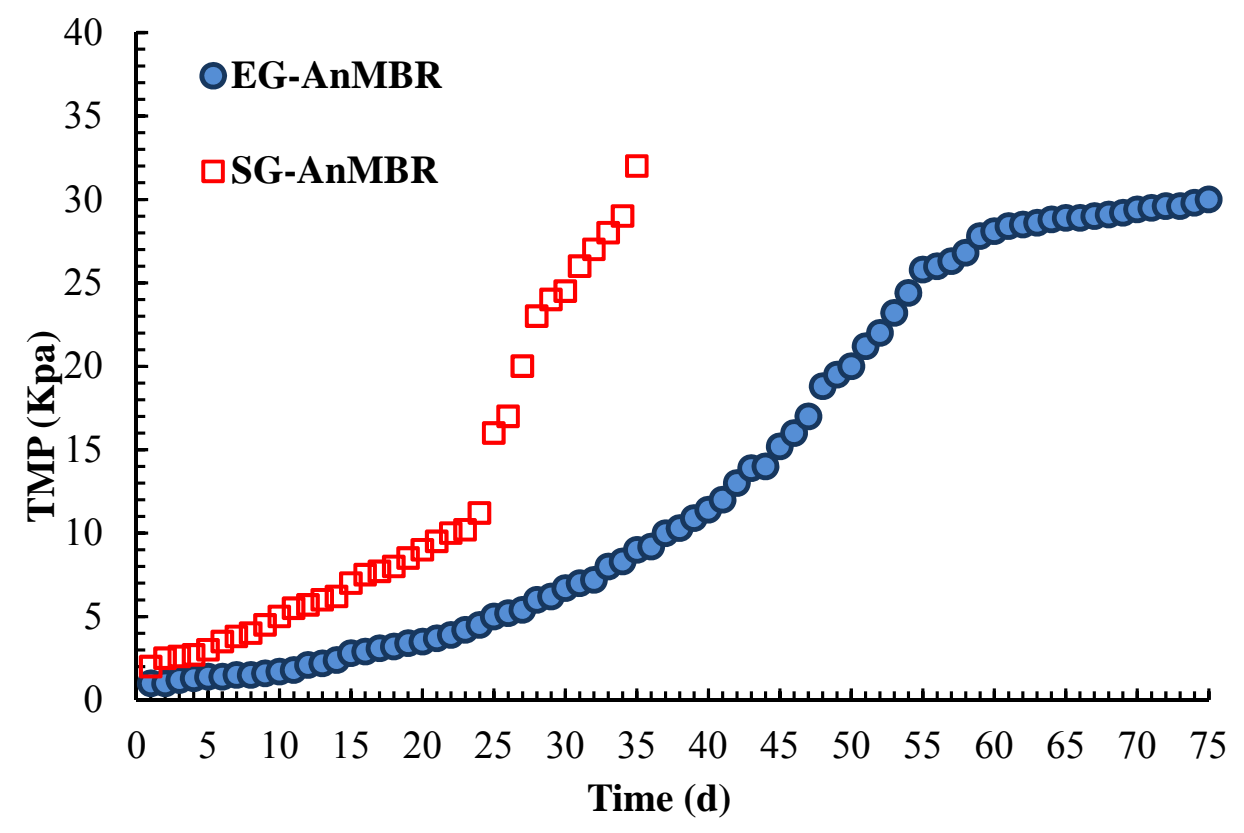

Fig. 1. TMP values of G-AnMBRs over the experimental period

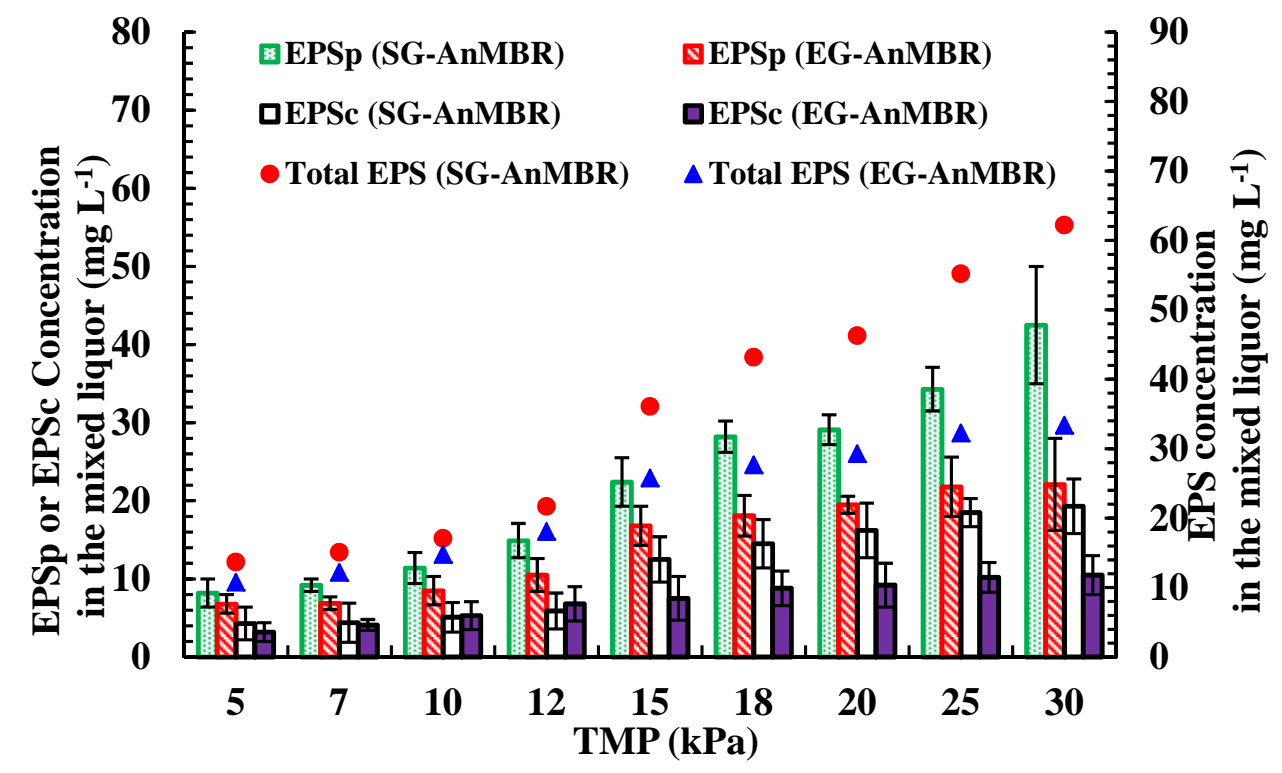

Fig. 2. Variations of EPS (including EPS $S_{P}$ and $E P S_{C}$ ) concentrations in the mixed liquor of SG-AnMBR settling zone and EG-AnMBR membrane tank 


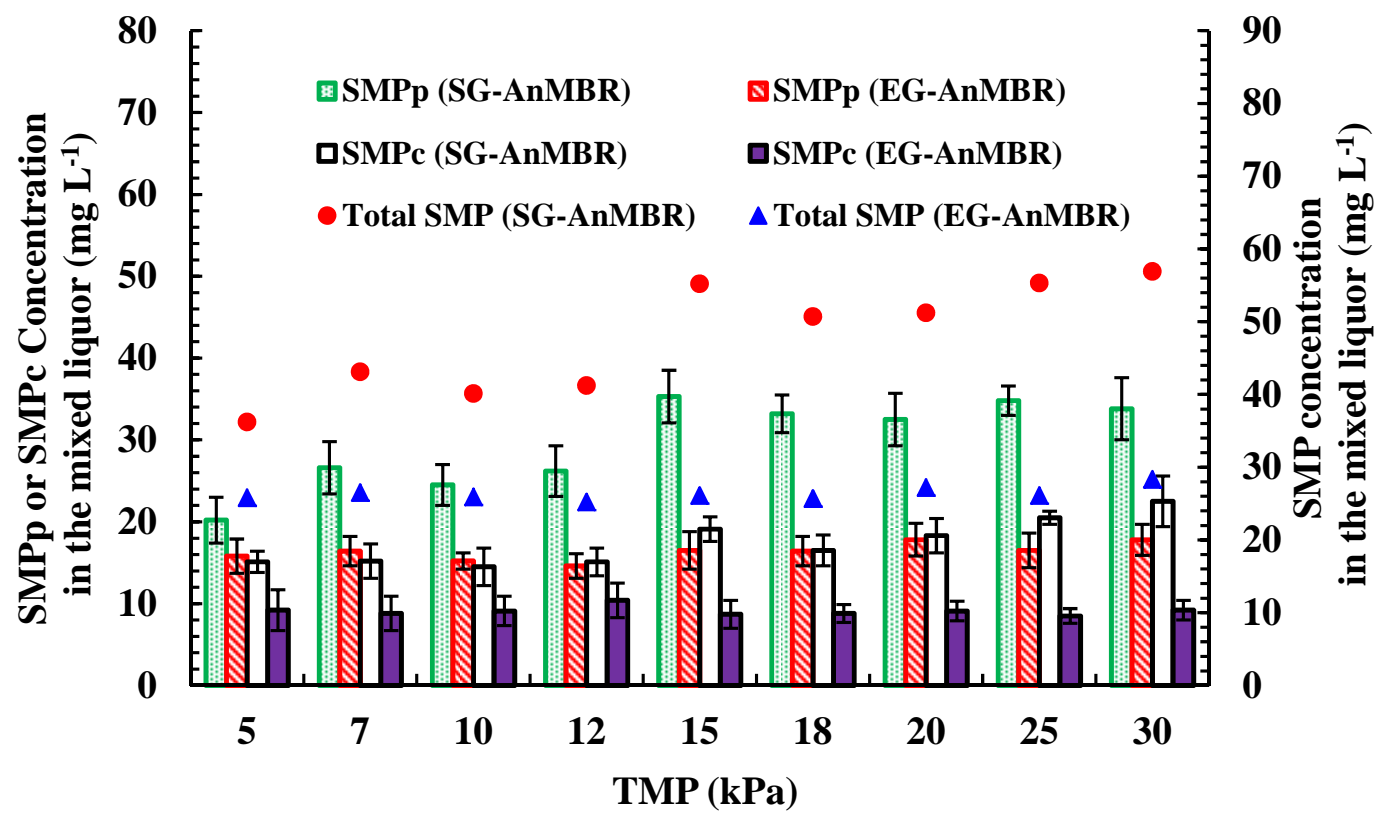

Fig. 3. Variations of SMP (including $\mathrm{SMP}_{\mathrm{P}}$ and $\mathrm{SMP}_{\mathrm{C}}$ ) concentrations in the mixed liquor of SG-AnMBR settling zone and EG-AnMBR membrane tank

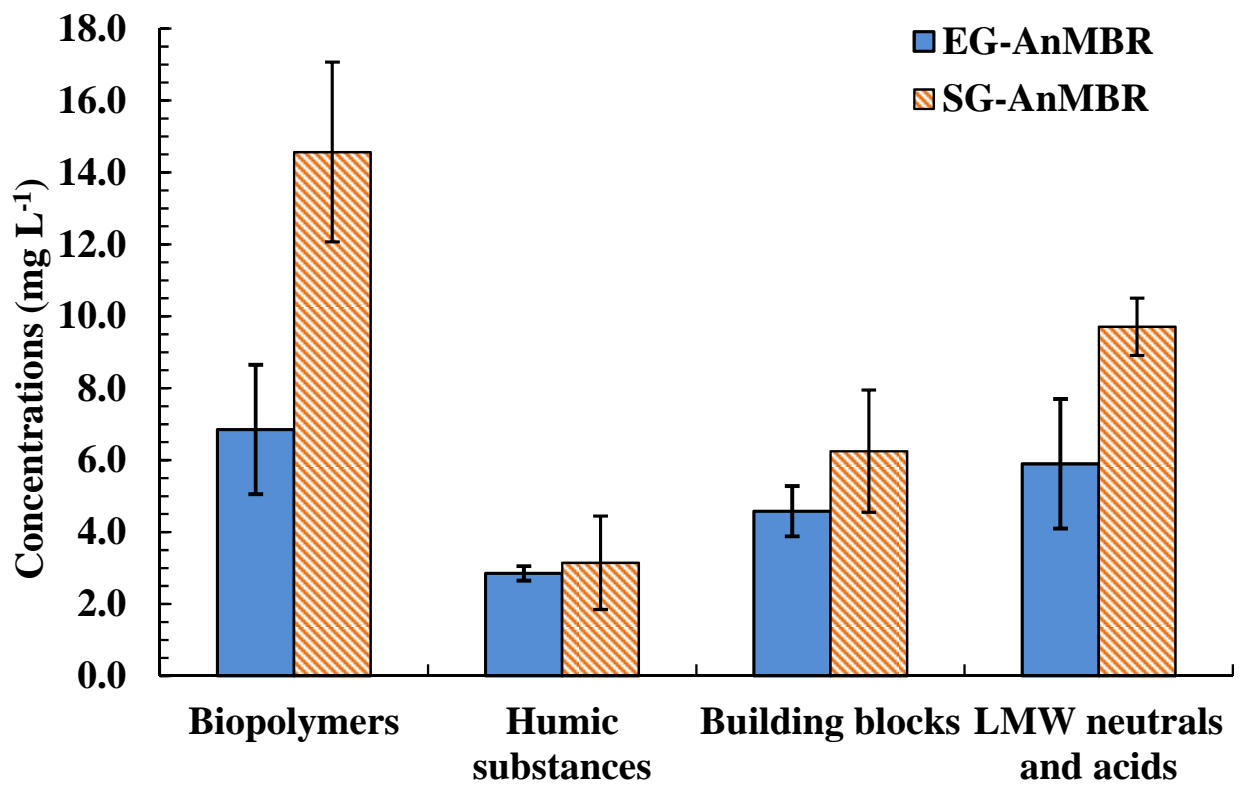

Fig. 4. Nature of foulant organics in the G-AnMBRs by LC-OCD analysis 